\title{
JUVENILE BLACKBIRD (Turdus merula) MOULTING PRIMARIES AND SECONDARIES
}

\author{
Monika Zielińska, Piotr Zieliński and Tomasz Mokwa
}

Zielińska M., Zieliński P., Mokwa T. 2005. Juvenile Blackbird (Turdus merula) moulting primaries and secondaries. Ring 27, 1: 121-123.

M. Zielińska (corresponding author), P. Zieliński, T. Mokwa, Institute for Ornithology, Polish Academy of Sciences, Nadwiślańska 108, PL-80-680 Gdańsk 40, Poland, Fax: +(4858) 308-09-82, E-mail: monicz@stornit.gda.pl

On 12 August 2004 while mist-netting in the garden of Institute for Ornithology in Gdańsk - Górki Wschodnie (N Poland) a juvenile Blackbird moulting primaries and secondaries was captured. The bird has been aged according to the guides of Busse (1984), Svensson (1992), Jenni and Winkler (1994). The mist-netted individual had typical juvenile plumage, brown body feathers and wing coverts with rufous shaft streaks, pointed rectrices and still well-visible bill-edges. All feathers were fresh and we were sure it was a first-calendar-year individual. In both wings we noted almost symmetrical active moult within the primaries as well as the secondaries. The moult stages have been described according to Ginn and Melville (1983) see Table 1.

Table 1

The moult scores (Ginn and Melville 1983) of captured Blackbird Turdus merula

\begin{tabular}{|c|c|c|c|c|c|c|c|c|c|c|c|c|c|c|c|c|}
\hline & \multicolumn{8}{|c|}{ Left wing } & \multicolumn{8}{|c|}{ Right wing } \\
\hline & \multicolumn{4}{|c|}{ Primaries } & \multicolumn{4}{|c|}{ Secondaries } & \multicolumn{4}{|c|}{ Secondaries } & \multicolumn{4}{|c|}{ Primaries } \\
\hline & $10-4$ & 3 & 2 & 1 & 1 & 2 & 3 & $4-6$ & $6-4$ & 3 & 2 & 1 & 1 & 2 & 3 & $4-10$ \\
\hline 12 Aug. & 0 & 0 & 1 & 1 & 5 & 4 & 0 & 0 & 0 & 0 & 0 & 4 & 5 & 0 & 0 & 0 \\
\hline 26 Sept. & 0 & 5 & 5 & 5 & 5 & 5 & 4 & 0 & 0 & 4 & 5 & 5 & 5 & 5 & 5 & 0 \\
\hline
\end{tabular}

In the left wing two innermost primaries were missing. The first secondary was new, fully developed and the second of them (also new) was more than two third grown. The rest of flight feathers in this wing were the first generation.

In the right wing the innermost primary was already new, full grown. The first secondary was being also renewed - more then two thirds grown. The rest of remiges of the right wing were juvenile. 
After ringing, taking measurements, weighing $(99.6 \mathrm{~g})$, determining the fat score (score 0 ) and describing moult scores the bird was released.

Over a month later, on 26 September this Blackbird was mist-netted once again in the same place by another ringer. The bird was examined carefully, because of the already noted unusual flight feathers for a juvenile Blackbird. The moult was more advanced than during the previous capture. Previously missing first and second primaries in the left wing had grown, and the third primary (previously present) had been renewed. The second secondary had already been fully developed and the third one was being replaced.

In the right wing the Blackbird had renewed succeeding primaries: the second and the third ones as well as the second and the third secondaries (Table 1). All body feathers were already new - blackish indicating this Blackbird was a male (Busse 1984, Svensson 1992). Almost all lesser and median coverts were new - only the first juvenile outermost median covert was retained. Greater coverts were typical of first-calendar-year Blackbirds with a moult limit between four or five postjuvenile coverts and the rest of them juvenile. All primary coverts and tertials had not been renewed. Only the flight feathers in the right wing were described by the ringer (Table 1). Tertials in this wing were also juvenile as well as all rectrices. This time the Blackbird was not weighed.

During more advanced juvenile moult, in a small number of Blackbirds, a few inner secondaries can be renewed - in addition to body feathers, wing coverts, allula and tertials (P6-P7) (Jenni and Winkler 1994). Mention is also made of young Blackbirds moulting or renewing single primaries or outer secondaries. Jenni and Winkler (1994) believed the renewal of single remiges was due to accidental feather loss. However, two facts exclude the possibility that the flight feathers were accidentally lost: first - the active moult in both wings of our captured Blackbird with neighbouring remiges in various stages of moult, second - the renewal of subsequent flight feathers in several next weeks. Due to the moult centre in mid-wing this feather replacement resembles the moult of adult individuals. In general, young Blackbirds as well as the other Turdus species do not undergo the moult of their flight feathers before the summer of their second calendar year of life. So, this is the first record of a juvenile Blackbird renewing primaries and secondaries and also the only data on such a moult in Turdus species (Baillie and Swann 1980, Busse 1984, Svensson 1992, Jenni and Winkler 1994). The rest of plumage were renewed typically (Svensson 1992, Jenni and Winkler 1994), though one can expect that the partial moult of primary coverts followed renewal of primaries.

\section{ACKNOWLEDGMENTS}

We are very grateful to Prof. Michael Thomas for the language correction of the manuscript. 


\section{REFERENCES}

Baillie S.R., Swann R.L. 1980. The extent of post-juvenile moult in the Blackbird. Ring. \& Migr. 3: 21-26.

Busse P. 1984. Key to sexing and ageing of European Passerines. Beitr. Natur. Niedersachsens 37, Suppl.: $1-224$.

Ginn H.B., Melville D.S. 1983. Moult in Birds. BTO Guide 19, Tring.

Jenni L., Winkler R. 1994. Moult and Ageing of European Passerines. Acad. Press, London.

Svensson L. 1992. Identification Guide to European Passerines. Svensson, Stockholm. 